\title{
At the Crossroads between Script Cultures
}

\author{
The Runic and Latin Epigraphic Areas of Västergötland
}

The late eleventh and early twelfth century constituted a pivotal period for the development of literacy in medieval Sweden. ${ }^{1}$ The Latin script and the Latin language, previously unattested in this part of Scandinavia, were gradually introduced into local writing practices that for centuries had been dominated by the use of the runic script and the vernacular language.

The arrival of Latin written culture, particularly manifest in the emerging manuscript culture, did not, however, cause the runic tradition to be abandoned, but led instead to several centuries of coexistence (e.g. Söderberg \& Larsson 1993: 62-66; Palm 1997; Spurkland 2001; 2004). This is particularly evident in the epigraphic sources, as Latin epigraphy gradually became established alongside runic epigraphy. Moreover, the spread of the new language and alphabet entailed far-reaching consequences for the existing runic epigraphy. One of the most apparent effects is the number of runic inscriptions that include passages in Latin or that are carved in the Latin language in their entirety (Düwel 1989: 48-51; 2001; Ertl 1994; Gustavson 1994a: 317-321; Knirk 1998: 484-489, 495-505). The introduction of Latin written culture also influenced both the runic writing system itself and the memorial formulas used on funerary monuments (see e.g. Liestøl in NIyR 6: 26, 34, 58; Gustavson 1994b: 74; 2013: 31; Knirk 1994: 206-207; 2010: 196; Steenholt Olesen 2007: 22-23; Källström 2013: 116; 2015: 135; Palumbo 2020: 232-234; forthcoming). On a more general level, the adoption of the Latin writing tradition is believed to have had an impact on the development of runic literacy, and it has been hypothesized that the adoption of the Roman script might have instigated a renaissance for runic epigraphy that was to last for over a century (e.g. Carelli 2001: 365-366).

Notwithstanding the interest that the relationship between runic and Latin literacy has attracted in previous research, most studies on this topic have either compared runic epigraphy with the Latin manuscript culture, or have focused solely on runic sources and on how runic writing was influenced by the Latin writing conventions. There is a lack of comparative studies on the relation between

1 Alessandro Palumbo's contribution has received funding from the European Union's Horizon 2020 research and innovation programme under the Marie Skłodowska-Curie grant agreement No. 839290.

Anna Blennow, University of Gothenburg

Alessandro Palumbo, University of Oslo

Ә Open Access. (C) 2021 Anna Blennow, Alessandro Palumbo, published by De Gruyter. (c) BY-NC-ND This work is licensed under the Creative Commons Attribution-NonCommercial-NoDerivatives 4.0 International License.

https://doi.org/10.1515/9783110695366-003 
these two traditions in a domain of writing where they actually can be directly correlated, namely the epigraphic material. ${ }^{2}$

The purpose of the present paper is to present a pilot study performed as the starting point for a larger collaborative project on the development of runic and Latin epigraphy, epigraphic habit, and literacy in medieval Sweden. This first step compares the establishment of the two epigraphic traditions in the province of Västergötland during the twelfth and thirteenth centuries. The perspective chosen combines epigraphic analyses with a geographical approach that aims to identify and characterize what we term "epigraphic areas" - i.e. the geographical areas where runic and/or Latin inscriptions are attested most frequently. This investigation will serve to shed light on where each of the two traditions was established, how they developed during the time under scrutiny, and how they relate to sociocultural centres such as monasteries, bishops' sees, and early towns. However, in order to understand the changes that these epigraphic traditions underwent, we believe it is necessary to analyse the use of both scripts in parallel and comparatively, as their developments during this time are deeply intertwined. As we will see, in some geographical areas, the nature of the two traditions' coexistence prompts the question of whether it is useful to talk about two separate script cultures, or whether the literacy practices there are better understood as part of a single two-script culture.

Central questions addressed in this investigation are thus whether the runic and the Latin epigraphic traditions occurred in the same areas or whether they had separate geographical domains, and whether the epigraphic areas identified resembled or differed from one another with regard to the number and kind of inscriptions attested, as well as the level of literacy and professionalism shown by the carvers. We will also investigate whether the relation between these epigraphic areas remained constant or rather changed over time, and whether their developments affected one another. Moreover, special attention will be given to the inscriptions where both Latin and runes are used together.

As already mentioned, the Swedish province of Västergötland has been selected as a case study. The reason behind this choice is that it is one of the areas in today's Sweden where Latin epigraphy arrived at an early stage, and where occurrences of both Latin and runic inscriptions are plentiful during the period under scrutiny. Furthermore, we will concentrate mainly on monumental and public epigraphy, rather than on inscriptions on movable objects from the private sphere. In contrast to inscribed loose objects - and manuscripts as well - monumental inscriptions are largely either still found in situ or have a secure provenance, which provides a reliable foundation for a geographical survey of the material. Such an analysis

2 Cf., however, Källström (2018: 70-73) and Kleivane (2019: 73-75), who draw parallels with Latin epigraphy to illustrate some features of runic orthography attested in selected inscriptions. 
can in turn serve as a basis for identifying socioculturally prominent areas and hubs of written culture, even when these are scarcely documented in other sources.

This pilot study focuses primarily on the geographical spread of the inscriptions in runes and in the Latin alphabet, combined with representative observations on the level of literacy shown in some of the texts included in the corpus. Thus, this study offers an overview of the radical geographical shifts in the epigraphic areas that took place during the earliest phases of contact between runic and Latin epigraphy. It also aims to test an interdisciplinary method of enquiry that unites the runologists' and the Latinists' perspectives on the complex relationship of two script cultures in early medieval Sweden. An in-depth textual and epigraphic analysis of each inscription, however, lies outside the scope of the present paper, as does an exhaustive consideration of the historical and archaeological context of each of the areas under scrutiny. To gain a nuanced understanding - as complete as it can be of written culture in medieval Scandinavia, these and other factors are, however, of great importance, and they will be taken into consideration in future investigations.

\section{The early medieval Latin and runic corpora in Västergötland}

The material analysed in this study is characterized by the varying use of two languages and two scripts: Old Swedish and Latin, the runes and the Latin alphabet. The inscriptions under scrutiny belong traditionally to two different corpora, the runic and the Latin ones. The distinction between them, however, is neither selfevident nor unproblematic. The defining criterion of the runic corpus is the use of runic script, independently of the language in which the texts are produced. The Latin corpus, on the other hand, is generally defined by the use of both the Latin alphabet and the Latin language. Of the inscriptions studied here, most are either in the Latin language and alphabet or in Old Swedish and runes. However, there are also examples of inscriptions in Old Swedish written with the Latin alphabet, and several instances where the Latin language is written in runes (see below). Furthermore, some artefacts bear mixtures of both languages and both scripts. Therefore, apart from the expected combinations of languages and scripts - i.e. runes and the vernacular on the one hand and Latin letters and the Latin language on the other - a diverse group of mixed inscriptions bears witness to the intricate and fascinating development of vernacular and Latin literacy in this area. 
The present paper primarily focuses on the geographical spread of the two scripts, and the terms Latin inscription and runic inscription will therefore be used to refer to the alphabet used, regardless of the language. ${ }^{3}$ However, in the overview below and in the following analyses, the language used will be taken into account when important to the argument.

Apart from the runic and Latin inscriptions, we operate with a separate category which includes biscriptal inscriptions, that is, inscriptions where both runes and Latin letters are employed. In this study, all text attested on the same artefact is regarded as one single inscription, despite the fact that different parts of it may be carved in different scripts, for in most cases the passages in runes and in the Latin alphabet can be proved to have been made by the same carver, and possibly composed by the same author.

The material chosen for this pilot study encompasses inscriptions that show a more or less marked formal or official character. They are found on artefacts such as funerary monuments, baptismal fonts, church bells, architectural elements in churches, and other objects such as reliquaries and altars (see Table 1). Inscriptions on smaller objects for private use, such as wooden sticks or everyday utensils, as well as informal graffiti inscriptions on church walls, have not been included. This has particular consequences for the selection of the runic material in our study, as a great deal of rune-carved loose objects from urban environments have not been taken into account. But since the provenance of monumental inscriptions is often known, such texts constitute a much more reliable basis for the study of the geographical spread of the two scripts than movable objects. Furthermore, monumental inscriptions can provide us with important insights into the competing role of the runes and the Latin alphabet in the public sphere. Lastly, there is to date no overview of movable artefacts inscribed with Latin letters, which makes it impossible to compare these Latin inscriptions with the corresponding and well-documented runic material.

3 Runic inscriptions are identified here by the standard practice of referring to the relevant volume and entry in the corpus edition, Sveriges runinskrifter (SRI); Vg 81, for instance, refers thus to the inscription number 81 in volume 5 of SRI, i.e. Västergötlands runinskrifter. Latin inscriptions on stone will be identified by their number in the edition of medieval Latin inscriptions in Sweden, 1050-1250 (Blennow 2016), or (for inscriptions on metal, or stone inscriptions after 1250) through reference to other relevant studies. 
Table 1: Overview by dating and artefact type of the runic, Latin, and biscriptal inscriptions studied. ${ }^{4}$

\begin{tabular}{|c|c|c|c|c|c|c|}
\hline & \multicolumn{2}{|c|}{ Runic inscriptions } & \multicolumn{2}{|c|}{ Latin inscriptions } & \multicolumn{2}{|c|}{ Biscriptal inscriptions } \\
\hline & $12^{\text {th }}$ century & $13^{\text {th }}$ century & $12^{\text {th }}$ century & $13^{\text {th }}$ century & $12^{\text {th }}$ century & $13^{\text {th }}$ century \\
\hline $\begin{array}{l}\text { Funerary } \\
\text { monuments }\end{array}$ & 16 & $19^{5}$ & 2 & 6 & 1 & 8 \\
\hline $\begin{array}{l}\text { Baptismal } \\
\text { fonts }\end{array}$ & 3 & 5 & 4 & $2^{6}$ & 0 & 0 \\
\hline Church bells & 0 & 7 & 3 & 7 & 0 & 1 \\
\hline $\begin{array}{l}\text { Other } \\
\text { artefacts }\end{array}$ & 0 & 0 & 3 & 0 & 0 & 0 \\
\hline $\begin{array}{l}\text { Architectural } \\
\text { elements }\end{array}$ & 4 & 5 & 6 & 0 & 0 & 0 \\
\hline Total & 23 & 36 & 18 & 15 & 1 & 9 \\
\hline
\end{tabular}

The corpus studied includes 102 inscriptions, most of which are found on funerary monuments. Their chronology primarily relies on archaeological, art-historical, and palaeographical analyses. ${ }^{7}$ The runic material makes up the greater part of the material and amounts to fifty-nine inscriptions, of which twenty-three are dated to the twelfth century and thirty-six to the thirteenth century. This latter category of inscriptions also includes three texts whose datings stretch across both centuries and place them from the end of the twelfth to the beginning of the thirteenth century. As regards the language of the runic inscriptions, most of them (forty-nine inscriptions) only consist of Old Swedish, nine contain either only Latin or a combination of both Old Swedish and Latin, and one is uninterpretable.

\footnotetext{
4 The material in this table is gathered from the corpora Sveriges runinskrifter, Sveriges medeltida latinska inskrifter 1050-1250 (Blennow 2016), Sveriges medeltida kyrkklockor (Åmark 1960), and academic journals where the relevant runic inscriptions have been published. The Latin inscriptions from the twelfth century included in the category "Other artefacts" have not yet been published, but consist of two reliquaries from Jäla (preserved in Västergötlands Museum, Skara, inventory number 1M16-1503) and Eriksberg (preserved in the Swedish History Museum in Stockholm, inventory number 5561), and an altar frontal from Broddetorp (preserved in the Swedish History Museum in Stockholm, inventory number 4674).

5 One thirteenth-century rune-inscribed grave slab, Vg 196 Älvsborg, has been excluded because its original location is unknown.

6 One presumably medieval, now-lost baptismal font with an inscription in Latin letters, Örgryte 1, has been excluded because it is only known from a description from 1692 with an unreliable transcription of the text (see Blennow 2016).

7 With two exceptions - the consecration inscription in Forsby (Forsby 1) and the runic text on a church bell from Saleby (Vg 210) - no inscriptions in the corpus of the twelfth and thirteenth centuries studied here include a date to a specific year.
} 
The inscriptions in Latin letters amount to thirty-three in total. The number of inscriptions is fairly stable during the two centuries studied: eighteen in the twelfth century and fifteen in the thirteenth century. Among the latter inscriptions, two are included whose dating stretches from the end of the twelfth to the beginning of the thirteenth century. As regards the language used in the Latin inscriptions, all of them, with one exception, are carved entirely in Latin. The exception is an inscription on a funerary monument (Valtorp 2) that includes both Old Swedish and Latin, carved entirely in Latin letters. The predominance of funerary monuments carved with runes over those with Latin letters in the twelfth century is striking, while we can see that in the thirteenth century, inscriptions totally or partly in the Latin alphabet (i.e. biscriptal ones) amounted to fourteen in total, compared with nineteen monoscriptal runic inscriptions. Where the other artefact types are concerned, the distribution of Latin and runic inscriptions is more even.

Regarding the biscriptal texts, ten inscriptions in the corpus under consideration include a combination of runes and Latin letters. One of these texts has a tentative dating to the twelfth century (Vg 54/Husaby 2), and a second one (Vg 221 Flakeberg) is dated to the second half of the thirteenth century, but all the others are concentrated between the end of the twelfth and the first half of the thirteenth century. Language-wise, these biscriptal inscriptions always show a combination of both Latin and the vernacular, with the exception of the aforementioned inscription Vg 54/Husaby 2, which has not yet been satisfactorily interpreted.

\section{The epigraphic areas in Västergötland}

To provide a background for the analysis of the epigraphic areas presented later in the paper, we will in the following section give an overview of some socioculturally important areas of Västergötland in the twelfth and thirteenth centuries. Thereafter, we will present the results of the geographical analysis.

\section{Religious and sociocultural centres of early medieval Västergötland}

What do we know about the province of Västergötland in the twelfth and thirteenth centuries? ${ }^{8}$ Archaeological and historical evidence is rather scant for the earliest part of the Scandinavian Middle Ages, and concerns mainly the bishop's see in Skara, founded in the eleventh century, the earliest monasteries established

8 In the following, we rely mainly on the general overviews of the history of medieval Västergötland found in Franzén (2002), Theliander (2004), and Lindkvist (2012). 
in the twelfth century, and the many parish churches that appeared from the early twelfth century onwards. Excavations have shown that Christianity arrived in the province much earlier than that: Christian burial places are found here already from the mid-tenth century. In Varnhem (for this and other locations, see Figure 1), recent excavations have confirmed a Christian presence already in the first half of the tenth century: a burial place with around three thousand tombs and the remains of a wooden church with a stone crypt, connected with a Viking-Age farming estate (Vretemark 2014).

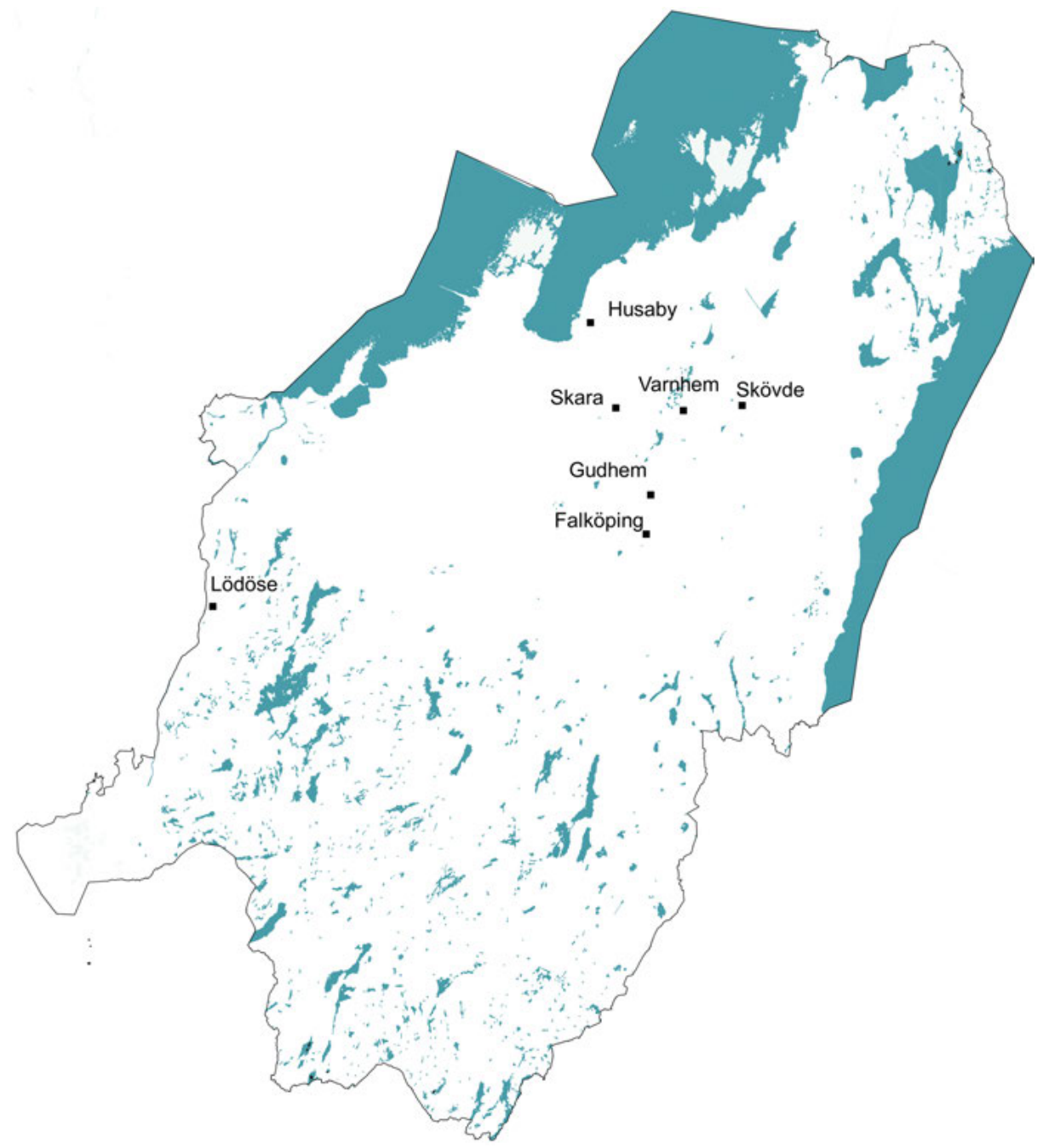

Figure 1: Map of sociocultural and religious centres of early medieval Västergötland. Map by Alessandro Palumbo. 
The area of Kinnekulle, a plateau mountain at Lake Vänern in northern Västergötland, is also a place that may have been especially connected with Christianity early on, according to the legend that King Olof Skötkonung was baptized at Husaby by Sigfrid, an English bishop, in the early eleventh century, and the unconfirmed tradition that Husaby was the oldest bishop's see in Västergötland, preceding the diocese of Skara, which is considered to have been founded in 1014 (the year when its first bishop, Thurgot, is mentioned in the sources). The first stone cathedral of Skara (of which nothing remains after a rebuilding in the thirteenth and fourteenth centuries) was probably built around 1060, but may have been preceded by a wooden church.

With the consolidation of the administrative structure of the Church in the early twelfth century, a large number of Romanesque stone churches were built all over Västergötland, with the highest frequency of parishes around Kinnekulle and today's Falköping. But it is not until the mid-twelfth century and later that the first monasteries are attested in Västergötland. At Varnhem, a male monastery is known to have existed from 1150. According to tradition, a group of Cistercian monks from the Alvastra monastery in the province of Östergötland (founded in 1143 by monks from Clairvaux) settled in Varnhem, where a certain Sigrid (possibly related to Queen Kristina, wife of King Erik) had donated land. The monastery and the church were destroyed in a fire in 1234 and rebuilt afterwards. In nearby Gudhem, a female Cistercian monastery was founded in 1170, after a donation of land by King Knut Eriksson in the vicinity of a kongsgård estate. In the mid-thirteenth century, one Dominican and one Franciscan monastery were founded in Skara, and a Dominican monastery was established in Lödöse. ${ }^{9}$

With time, several settlements in Västergötland grew into the first towns; most of them were situated in the central-north parts of the province. Skara is mentioned in the Gesta of Adam of Bremen in the 1070s, and archaeological remains are found from around 1050, but the area is believed to have already been important during the Iron Age (Sigsjö 1980: 10). Skövde is mentioned for the first time in a charter from 1281 (DS 709), but no traces of an actual town have been found from before the early fifteenth century. The greater part of the old town centre has been lost due to later rebuilding, which makes a reconstruction of its medieval history difficult. A cult of the local saint, Elin/Helena, is attested in Skövde in the early twelfth century (Klackenberg 1980: 10). The earliest settlements around today's Falköping go back as far as ten thousand years, and it is mentioned as a market place in the late thirteenth century, a function that it had probably already held for a long time. It is not until 1281 that Falköping is explicitly mentioned as a town, in the charter of Bishop Brynolf (an appendix to Västgötalagen). Very little is known of its medieval history due to the lack of archaeological excavations and/or remains (Klackenberg 1981: 10). Lödöse stands out as the only early town in the western part of Västergötland. Archaeological remains from the second part of the eleventh century have been found here. The town is mentioned in the

9 See Karlsson (1993). For the Alvastra monastery, see Bonnier (2012). 
sources for the first time in 1151, when Saxo, among others, attests that the Danish king Knut Magnusson landed there (Carlsson \& Ekre 1980: 6). It must, though, be kept in mind that only a small percentage of the population of Västergötland lived in these early towns or settlements in the twelfth and thirteenth centuries.

As seen in Figure 1, all the aforementioned locations are situated in a fairly welldefined area in the central and mid-northern regions of Västergötland, with the exception of Lödöse in the west. How does this geographical pattern correspond to the epigraphic areas of the twelfth and thirteenth centuries? In the following, we will show how geographical analysis of the runic and Latin epigraphic monuments delineates partly new and somewhat surprising areas of sociocultural importance in the province.

\section{Epigraphic areas up to and including the eleventh century}

The oldest epigraphic tradition present in Västergötland is the runic one, which starts long before the Scandinavian Middle Ages. There are a few Proto-Norse inscriptions from the period AD 300-600, but it is the geographical spread of runic inscriptions from the tenth and eleventh centuries that is of relevance for the present study. During this timeframe, two types of runic monuments were produced: the rune stones and the so-called early Christian grave monuments. Despite the fact that only the monuments of the latter type are explicitly called Christian, it should be pointed out that a majority of the inscriptions on the rune stones are believed to have been produced in a Christian context too.

The Viking-Age rune stones from Västergötland, for the most part erected from the late tenth century and throughout the first quarter of the eleventh, are concentrated in what can be defined as three major epigraphic areas (SRI 5: xxvii; Palm 1992: 92-93; see Figure 2): Redväg Hundred in the central part of the province south of Falköping, Kålland Hundred in the north, and Vadsbo Hundred in the north-east. ${ }^{10}$ Of these three areas, Kålland Hundred is richest in monuments.

At least partly contemporary with the rune stones, the so-called early Christian grave monuments were produced during the first half of the eleventh century. They differ from the rune stones through their localization directly at the tomb (they are hence funerary monuments rather than cenotaphs), and through their shape, consisting of

\footnotetext{
10 In his study from 1992, Rune Palm focused on the geographical patterns evident in Viking-Age and medieval runic inscriptions. Differently from the present study, which differentiates between Viking-Age and medieval material on the basis of the inscriptions' dating, Palm operated with a typological differentiation between raised and recumbent stone monuments, and dated the former to the Viking Age and the latter to twelfth century. Such a way of grouping the inscriptions, however, faces the problem that some recumbent slabs belonging to the corpus of so-called early Christian grave monuments may be from the same period as the Viking-Age rune stones, and so the categories established by Palm very likely overlap in time (Ljung 2016: 101).
} 
lying slabs with or without head- and foot-stones, or more or less elaborate coffin-like constructions, ornamented in the same Viking-Age styles as many rune stones (Ljung 2016: 14-19; 2019: 156-156). Some of them bear runic inscriptions. Examples of these monuments can be found in several Swedish provinces, indicating a widespread, although varying practice. In Västergötland, most occurrences have been found in the northern parts of the province (Ljung 2016: 92; 2019: 159; see Figure 2), mainly in Husaby (Kinnekulle area) and in Råda and Häggesled (Kålland area).

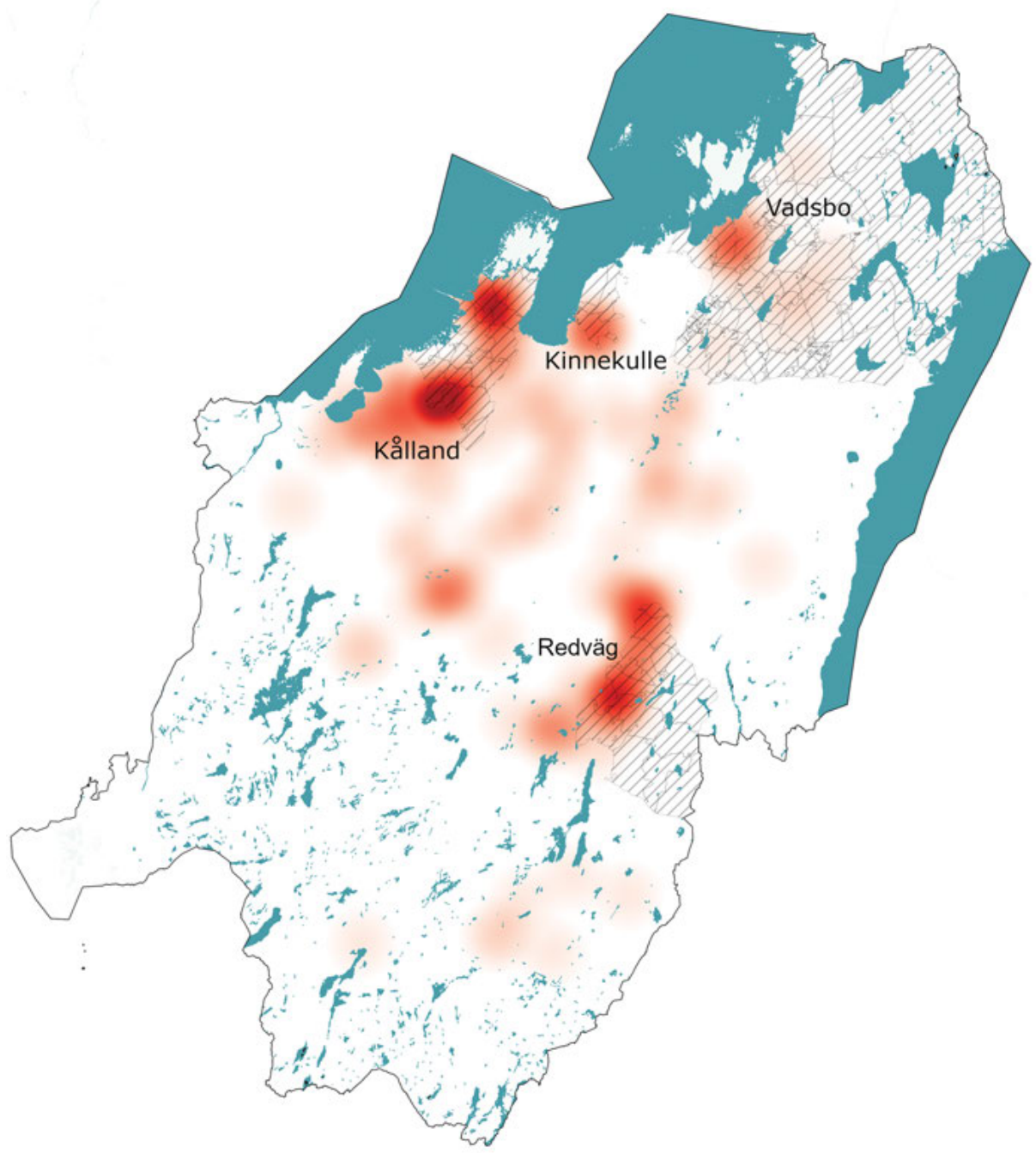

Figure 2: Heatmap of rune stones and the rune-inscribed early Christian grave monuments in Västergötland showing the four major eleventh-century epigraphic areas (marked with diagonal lines), which are located in Redväg Hundred, Kålland Hundred, Vadsbo Hundred, and Kinnekulle (Kinne and Kinnefjärding Hundreds). Map by Alessandro Palumbo. 
Cecilia Ljung (2016: 102) has pointed out that in general, the spread of these early Christian grave monuments coincides with some of those areas of Västergötland which also show the greatest concentration of Viking-Age rune stones.

At this point in time, the runic tradition constitutes the only form of epigraphy attested in Västergötland. No Latin inscriptions securely dated to the eleventh century are found in the province; in the entire corpus of Latin inscriptions in Sweden from the early Middle Ages, there is only one inscription securely dated (stratigraphically) to the eleventh century: a fragment of an early Christian grave monument in Linköping Cathedral in the province of Östergötland (Blennow 2016: Linköping 1).

\section{The twelfth century - innovation and development}

During the twelfth century, two major changes affect the nature and location of Västergötland's epigraphic areas: the appearance of Latin epigraphy and a shift in the runic epigraphic areas.

As regards runic epigraphy, the monuments dated to the twelfth century mostly grave slabs and baptismal fonts - show a different distribution compared to the aforementioned epigraphic areas where the Viking-Age rune stones and the early Christian grave monuments are found. Strong Viking-Age epigraphic areas in the hundreds of Kålland, Vadsbo, and Redväg decline in importance, whereas a new area (see Figure 3) located around the modern-day town of Falköping gains a more prominent role (cf. Palm 1992: 114-116; 1997: 90). Concentrations of runic inscriptions are now found in the Falköping area, in the hundreds of Gudhem, Valle, and Kåkind (north and north-east of Falköping), and in the hundreds of Vartofta, Frökind, Redväg (northern part), and Vilske (south and east of Falköping). Gudhem in particular stands out as the hundred with the highest concentration of runic monuments, which might be due to a stronger presence of both religious centres (e.g. the Gudhem monastery) and worldly power in the area. The northern part of this area clearly shows a denser concentration of runic inscriptions compared to the south-eastern part, where the inscriptions are more scattered.

Thus, we can detect a clear geographical shift in the twelfth-century runic epigraphic areas compared with the Viking-age ones, consisting in a concentration of the runic tradition in the central part of the province. 


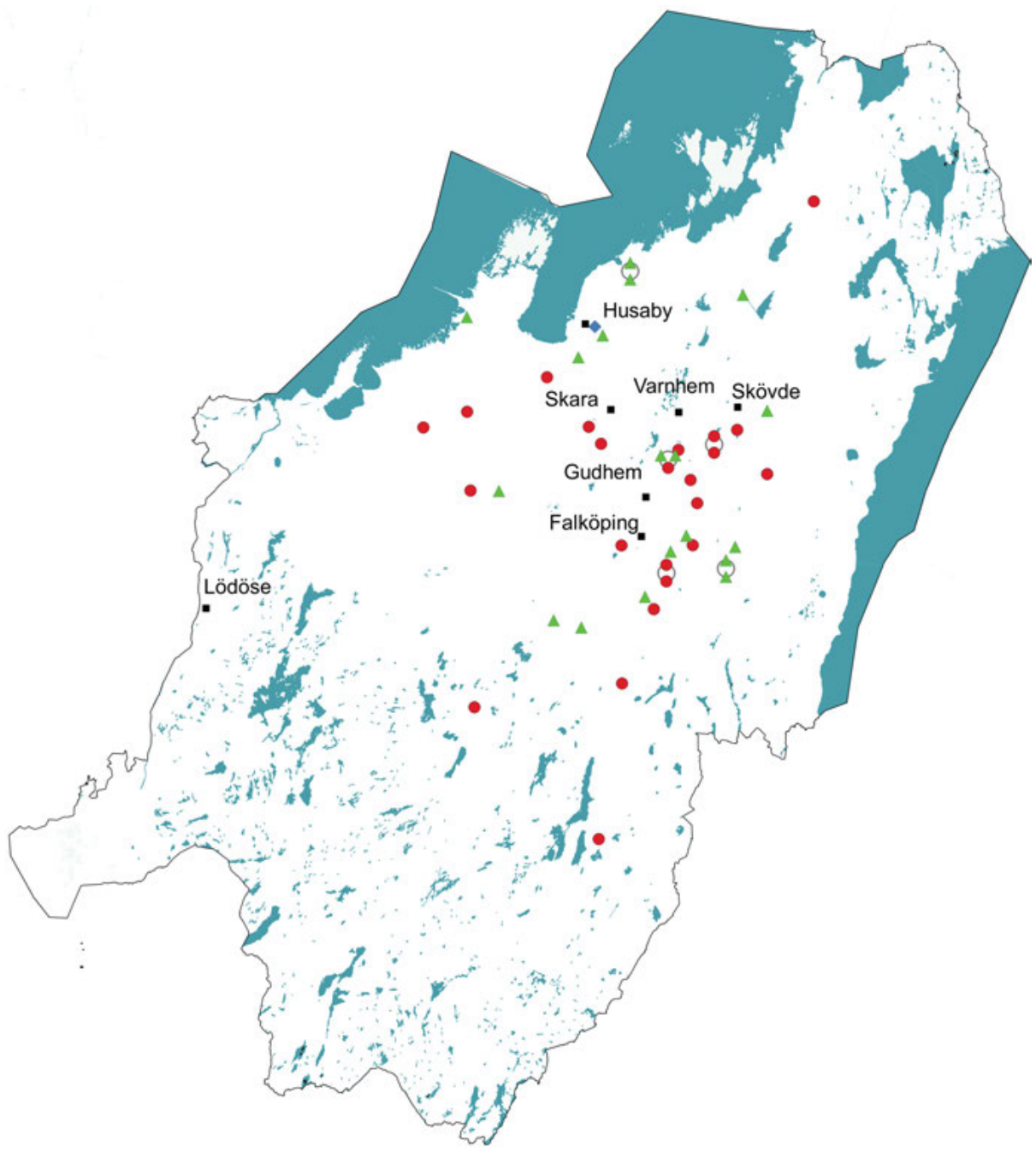

Figure 3: Map of the runic (red dots), Latin (green triangles), and biscriptal (blue diamonds) inscriptions from the twelfth century. Map by Alessandro Palumbo. 
A representative example of the runic tradition from this period is the inscription on a funerary monument from Broddetorp (Vg 81; Figure 4). Its chiefly Old Swedish text reads as follows: ${ }^{11}$

\section{benḍikt • romfarari : let gera : hualf : penna : ifir · magnus · kopan dræg • ---- s. . . ok : dọ : hạn om nat : firir · peira : postla : messoạftan : simonis : æð iute : in pat er $\cdot$ ret $\cdot$ hu. . . . . .}

Bendikt rōmfarari lēt gæra hvalf penna yfir Magnūs, gōðan dræng . . . Ok dō hann om nātt fyrir pæira postla mæssoaftan Simonis et Iudæ. En pat er rētt hv[ærium at biðia Pater].

Benedict the Rome-traveller had this vault made over Magnus, a good valiant man . . . And he died in the night before the eve of the Mass of the apostles Simon and Juda. And it is right for everyone [to pray the paternoster].

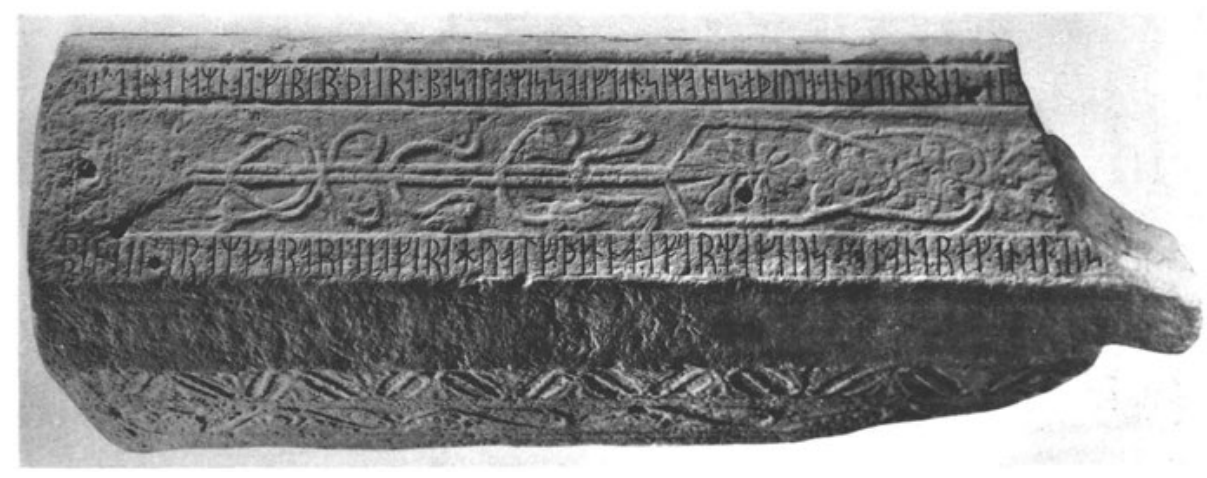

Figure 4: Rune-carved funerary monument from Broddetorp (Vg 81), Gudhem Hundred. Photograph by Harald Faith-Ell.

This monument and its inscription form part of the flourishing epigraphic area north of Falköping, contributing to the considerable number of epigraphic texts stemming from Gudhem Hundred. Both the orthography and the wording of the inscription bear witness to a high degree of literacy.

The text shows orthographical features that are either absent or very rare during the Viking Age, such as the double-spelling of long consonants and the use of dedicated

11 The text in bold is a transliteration of the inscription; an Old Swedish normalization is given in italics. Dashes in the transliteration signal now-unreadable runes. A dot under a transliterated rune indicates that the rune in question is damaged and its reading unsure. Three dots mark lacunae, and square brackets indicate reconstructed text passages. The end of the inscription, with the request to the reader to read the paternoster, is reconstructed on the basis of another twelfth-century runic inscription from Västergötland, Vg 76 Backgården (Valle Hundred in the Falköping region), which bears the same formula: pat er rētt hværium at biðia Pater. 
runes for the sounds $[\varepsilon]$ and [ð], for instance in the word æð for the Latin conjunction et. Such medieval innovations are part of a series of changes that the runic script underwent during the Middle Ages. Many of these developments consisted in an expansion of the runic alphabet through the modification of certain runes, either with regard to their shape or their function. In medieval Sweden, these developments appear at different times and show varying degrees of consistency of use, depending on the region. While the general chronological tendency is that their employment becomes more widespread from the twelfth to the thirteenth century, many of these innovations seem to have had their Swedish starting point in the aforementioned epigraphic area around Falköping, especially in the hundreds of Gudhem and Vartofta (Palumbo 2020: 227-230).

Another important feature of the inscription from Broddetorp is that it also bears evidence of the influence that the Latin epigraphic tradition exerted on the runic tradition, both linguistically and socioculturally. The aforementioned doublespelling of long consonants, for instance, is surely a consequence of such influence (see e.g. Peterson 1994: 74; Gustavson 1994a: 324; 1994b: 74; Palumbo forthcoming). Elements in the Latin language can also be found, namely in the reference to the Lord's Prayer, the paternoster, and in the liturgical dating to the eve of the Mass of the apostles Simon and Juda, where both the names in the genitive and the conjunction et are in Latin, embedded in an otherwise vernacular text. The liturgical dating itself is a unique feature in the corpora under consideration, both the runic and the Latin one, and is inspired by the Latin epigraphic tradition on the continent. $^{12}$ These traits may anticipate (or be more or less coeval with) the bilingual and biscriptal culture that emerged in the Falköping area, probably towards the end of the twelfth century (as described below).

The runic attestations in the Falköping area, their concentration, their dating, and their orthographical and textual features, seem to testify to a renaissance of the runic epigraphy in that part of the region. As we will see below, this geographical area also coincides with one of the early Latin epigraphic areas in Västergötland.

The first Latin inscriptions in Västergötland are attested from the first half of the twelfth century. Why did Latin epigraphy arrive in Västergötland at this point in time? It was not prompted by a newly performed conversion to Christianity as we have seen, the Christian religion had been introduced to the region over a hundred years earlier. Most probably, the introduction of Latin epigraphy was instead connected with the stabilization of the administrative structure of the Church (see e.g. Dahlberg 1998: 77-79), which led to the large-scale building of stone churches all over the region, and which brought stonemasons more or less versed in a European tradition of Latin epigraphy to Scandinavia. The twelfth

12 In the corpus of Latin consecrative inscriptions from Rome of the twelfth and thirteenth centuries, liturgical dating becomes common in the late twelfth century, and from the 1230s it is used almost exclusively in the inscriptions. See e.g. Holst Blennow (2011: 256-257). 
century also brought the first monasteries to Västergötland - important nodes for written culture in general, including epigraphic knowledge.

The locations of the Latin inscriptions show that the emerging Latin epigraphic tradition both overlaps with and differentiates itself geographically from the runic one. The Latin inscriptions appear in two main epigraphic areas (see Figure 3): in the Kinnekulle area, where the medieval runic tradition, by contrast, appears to be almost non-existent in this period, and in the Falköping area, where, as we have seen, runic inscriptions are also found.

Some variation regarding textual content can be found in the two epigraphic areas. The Kinnekulle inscriptions exhibit liturgical content, such as information regarding church consecrations, to a greater degree. An example can be found in an inscribed tympanum relief in the church in Forshem (Forshem 1; Figure 5). It is situated above the south door of the church, and depicts Christ surrounded by the apostles Peter and Paul. The first part of the inscription runs along the border of the tympanum, and reads: ${ }^{13}$

Ist[---] sit in honore D(omi)ni n(ost)ri Ie(s)u Ch(rist)i et s(an)c(t)i sepulcri

May this [---] be in honour of our Lord Jesus Christ and the Holy Sepulchre.

The second part of the inscription is situated below the relief, and consists of the Latin alphabet, ending with the Greek letter omega.

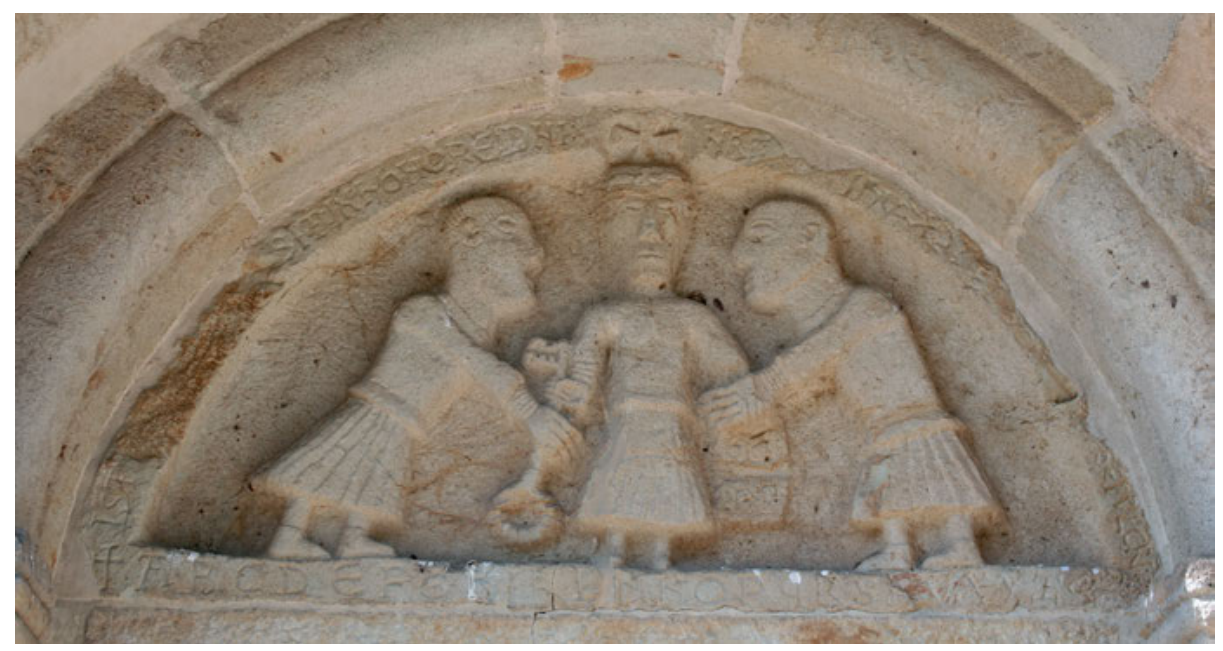

Figure 5: Latin inscription on the tympanum field above the south door of the church of Forshem (Forshem 1; photograph by Anna Blennow).

13 Abbreviations are spelled out in parentheses. Three dashes within square brackets signal a lacuna where the number of lost letters is unknown. Text within square brackets renders reconstructed passages. 
The lacuna in the inscription is due to damage to the stone and has previously been conjectured as ecclesia, 'church', thus signifying that the church was consecrated to Christ and the Holy Sepulchre. But, as recently shown by Anna Blennow (2016), the lacuna most probably contained the word elemosina, 'alms', meaning that the building or the consecration of the church was funded as an act of charity by a wealthy patron. It has also been suggested that the mention of the Holy Sepulchre implies that the church must have possessed a relic of the Sepulchre, perhaps brought there by someone with connections to the Crusades to Jerusalem. The style of this and several other stone reliefs preserved in the church has been attributed to the stonemason who produced decorations for the now-lost Romanesque cathedral of Skara - they, however, lack inscriptions, which could mean that the incentive for making an inscription was to be found in Forshem, perhaps deriving from the patron of the church.

While the Kinnekulle area is characterized by the presence of liturgical inscriptions, the two Latin funerary inscriptions preserved from the twelfth century are found instead in the Falköping area. These long and elaborate inscriptions (Åsle 1, Figure 6; Vårkumla 1) show a radical break with the tradition of runic funerary epigraphy in the area - they are composed more or less in verse, and use a highly stylistic Latin with elaborate formulas. This points to the presence in the Falköping area of advanced authorial competence in Latin, a fact not attested in previous research.

The fragmentary and heavily worn inscription rediscovered in Åsle cemetery by Anna Blennow in 2016 has not been interpreted in its entirety due to its worn surface, but elements such as generose 'nobly', moribus insignis 'excellent regarding manners',
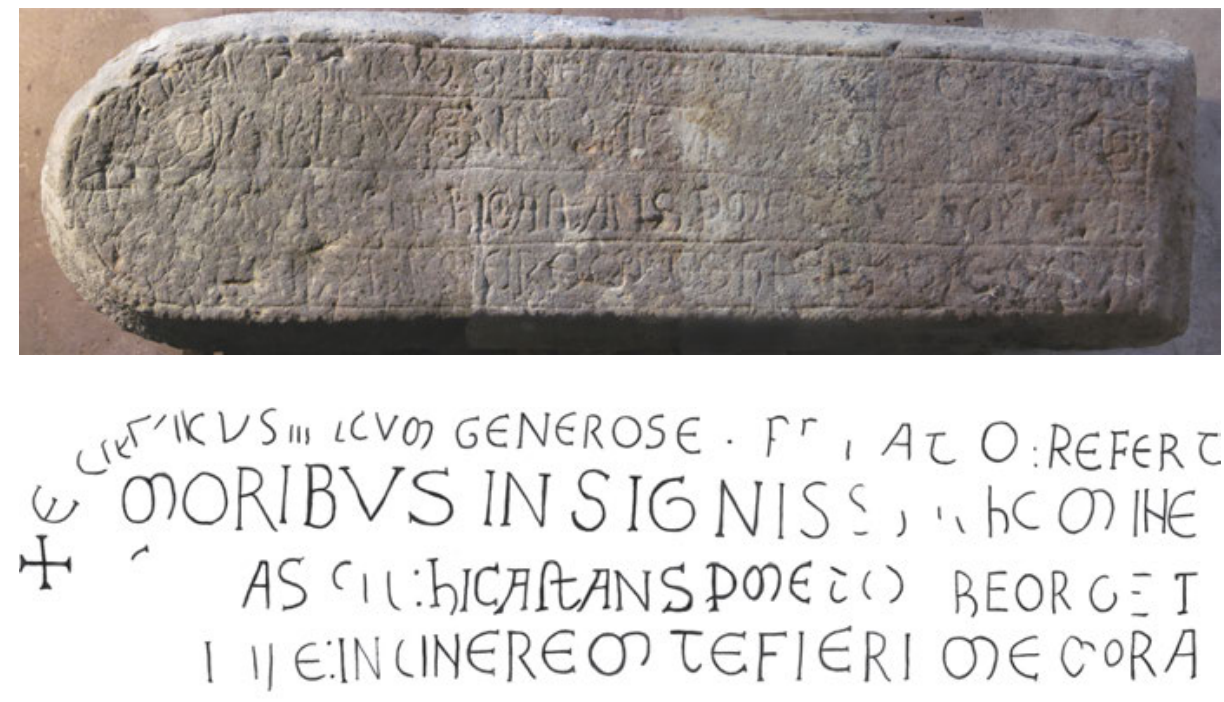

Figure 6: Fragmentary Latin inscription on funerary monument from Åsle Church, Vartofta Hundred (Åsle 1). Photograph and drawing by Anna Blennow. 
and hic astans p(ro) me [ora] '[pray] for me, you who stand here' can be deciphered, as can the tentative reading of the female name Torbeorg (near the end of line 3).

The Latin inscription on the funerary monument from Vårkumla, made in memory of Hanes, a Benedictine priest, was interpreted in its entirety for the first time by Blennow (2016: 201-205) and reads Presbiter ordine Benedicti nominetur / Hic resuscitet Hanes hoc marmore teste, 'May the priest Hanes of the Benedictine Order be mentioned/appointed. Here Hanes will arise with this stone as witness.'

The two funerary inscriptions from Åsle and Vårkumla testify to an advanced Latin epigraphic literacy previously unattested in the Falköping area in the twelfth century, a fact that provides an important background to the bilingual and biscriptal culture documented in the area towards the end of the twelfth century (for which, see below).

Latin inscriptions on precious metal objects are found on two reliquaries in wood covered with gilded copper, from Jäla and Eriksberg, and on an altar frontal in wood covered with gilded copper from Broddetorp, all of them located in or near the Falköping area. Two of the three occurrences of inscribed church bells tentatively dated to the twelfth century are also found in the Falköping area. ${ }^{14}$ Thus, we can see that Latin inscriptions on metal are found mainly in connection with the epigraphic area around Falköping, something which makes this region richer in variety where the material of the inscriptions is concerned, and also, in the case of the reliquaries and the altar frontal, indicates the presence of wealthy individuals providing financial support to the church.

As previously pointed out, it is probable that the introduction of Latin epigraphy to Västergötland was prompted by the spread of Latin literacy that came with the gradual consolidation of ecclesiastical structures and the presence of international craftsmen and stone-cutters connected with the large-scale building of stone churches all over the province. But the fact that the Latin inscriptions are so few in relation to the overall number of churches from this period - around three hundred - suggests that the incentives for adding a text to a monument were more complex and rarer than the incentives for manufacturing the monument itself, an issue we intend to address in a future study.

\section{The late twelfth and early thirteenth centuries: expansion of both Latin and Runic areas}

Towards the end of the twelfth century and in the thirteenth century, we can observe a change both in the location of the runic and Latin epigraphic areas, and in the use of the two scripts, which consists in their combined employment in the same inscriptions.

14 Karleby (Vartofta Hundred), Valstad (Vartofta Hundred), and Tråvad (Laske Hundred); see Åmark (1960). 
During this timespan, both the runic and the Latin epigraphic areas undergo similar developments: a consolidation of previous epigraphic areas and an expansion to other sites in the province. As regards the runic tradition, the aforementioned area around Falköping retains its character as a hub of epigraphic production. At the same time, the runic script expands its domain, as runic inscriptions are attested in a wider geographical region than during the twelfth century, one that includes an epigraphic area around Skara (with especially frequent attestations in Saleby Parish), as well as the epigraphic area in Vadsbo Hundred in the north-east (see Figure 7).

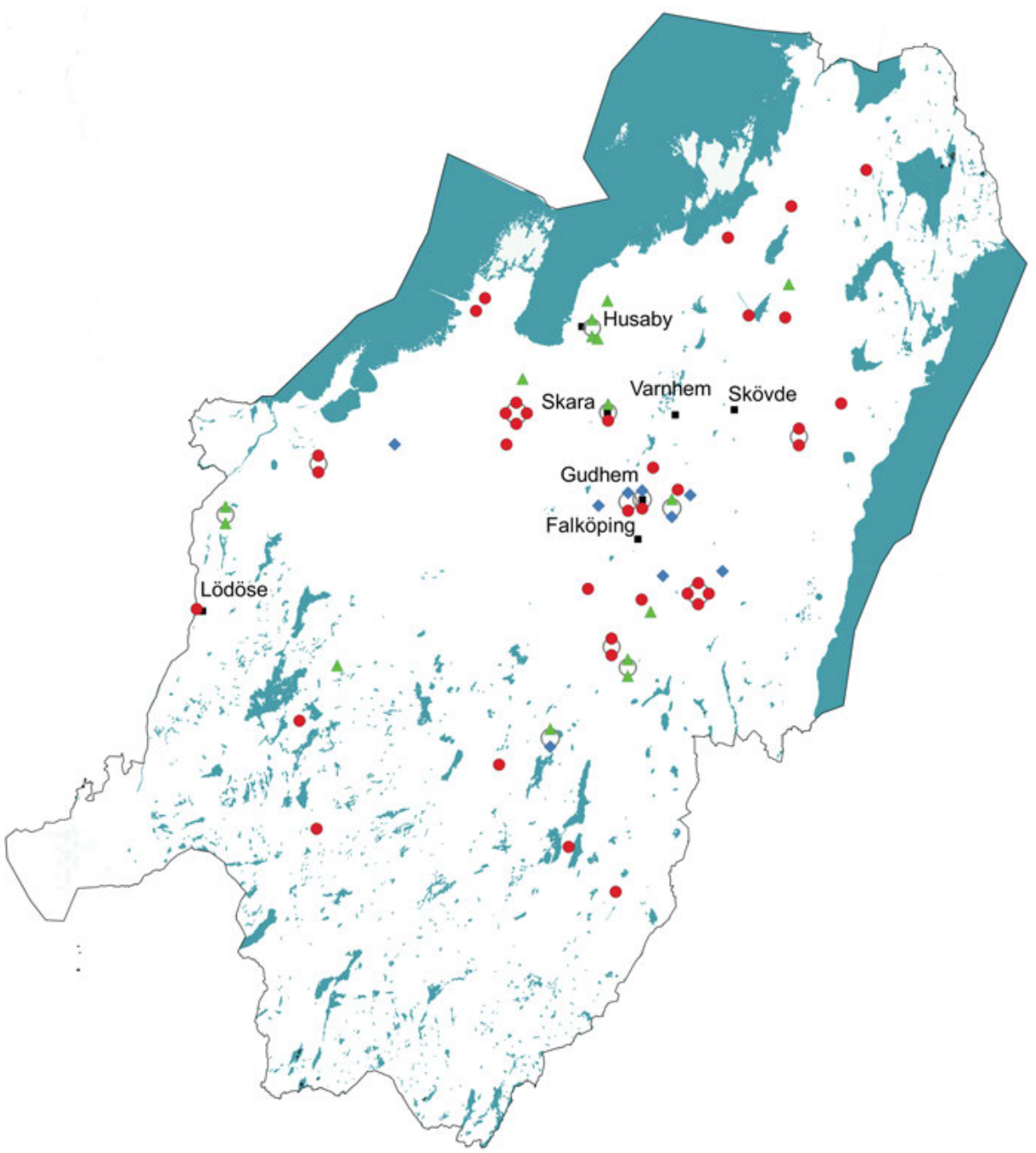

Figure 7: Map of the runic (red dots), Latin (green triangles), and biscriptal (blue diamonds) inscriptions from the late twelfth century and the thirteenth century. Map by Alessandro Palumbo. 
While the epigraphic area around Skara resembles that of Falköping with regard to the type of inscriptions present there (see below), the area of Vadsbo seems to have had a more marginal character. First, in Vadsbo the inscriptions are not as concentrated as those in the Falköping area. Because of its fairly large size compared to other hundreds, the inscriptions appear quite scattered. Also, the types of inscriptions and artefacts that are found here might indicate that this region was more peripheral regarding literacy compared to the Falköping area. Of the five inscriptions from the thirteenth century found in Vadsbo, only one is on a grave slab, whereas a second is partly a maker's signature on a door fitting, and the remaining three are all futhark inscriptions on church bells - i.e. inscriptions which only consist of the rune-row fuporkhniastblmR. In these last three cases, the script-bearing objects are less bound to the area where they have been found than grave slabs, meaning that they could have been imported from more central epigraphic areas, and the inscriptions themselves show a lower degree of literacy.

An artefact which both exemplifies this geographically expanded epigraphic manufacturing and the possible discrepancy between the inscriptions' place of production and their distribution (see also below) is a church bell from Saleby Church (Vg 210), east of Skara. This and three fragmentary thirteenth-century gravestone inscriptions testify to a spread of the runic tradition to this new epigraphic area. As pointed out before, the tradition across the Skara area furthermore seems to differ from the other aforementioned thirteenth-century epigraphic area, Vadsbo Hundred. Apart from the more geographically confined distribution of the Saleby inscriptions, the texts produced here show a higher degree of acquaintance with writing than those in Vadsbo, and the church bells from these localities are a case in point. Whereas the bells in Vadsbo Hundred bear inscriptions containing variations of the rune-row fuporkhniastblmR, ${ }^{15}$ the Saleby bell inscription consists of a longer bilingual text, entirely in runes, that includes a part in Old Swedish, a sequence in Latin, and the Hebrew Kabbalistic acronym agla:

pā iak var gør, pā var pūshundrað tu hundrað tiugu vintr ok ātta frā byrð Guðs. Agla. Ave Maria gratia plena. Dionysius sit benedictus.

When I was made, it was a thousand two hundred and twenty winters and eight from God's birth. Agla. Hail Mary, full of grace. May Denis be blessed.

Inscribed artefacts like church bells raise the question of whether they testify to epigraphic traditions and literacy practices of the place where they were produced, or rather of the localities where they were used, as further discussed below. The Saleby church bell represents a thought-provoking example in this respect as well. It is believed to be the work of a craftsman named Sköldulv, who cast another rune-inscribed

15 The relevant church bells are from Färed Church (Vg 203), Odensåker Church (Vg 205 †), and Älgarås Church (Vg 206). 
bell found in Tibro Church (Vg 219), in the same province of Västergötland but in Kåkind Hundred in the Falköping area (Åmark 1960: 241). This latter bell can in turn be connected to a third one from the province of Småland, in Burseryd Church (Sm 49), since both are apparently signed by the same carver, Björn. Closing the circle, the runic inscription on the Burseryd bell shows interesting textual similarities with the one on the Saleby bell, since both use the same kind of dating. ${ }^{16}$ However, despite the connections between these three church bells, the language choices in their runic texts differ from one another. In fact, the Saleby inscription is carved in Swedish and Latin, the text from Tibro is solely in Swedish, and the one from Burseryd is entirely in Latin.

In the late twelfth century and the first half of the thirteenth century, the location of the Latin inscriptions confirms the tendencies seen in the runic material, namely a continued importance of the twelfth-century epigraphic areas as well as a spread of epigraphic monuments over larger areas in Västergötland (see Figure 7). Latin inscriptions are still found in the two main areas of Kinnekulle and Falköping, while new areas also come into play. As for the runic inscriptions, they are now found in the Vadsbo area as well as in the Skara area (e.g. the funerary inscription in Figure 8), but also in new, isolated localities in the western part of the province, namely Flundre and Kulling Hundreds (Figure 7). ${ }^{17}$ Interestingly, Latin inscriptions are now attested

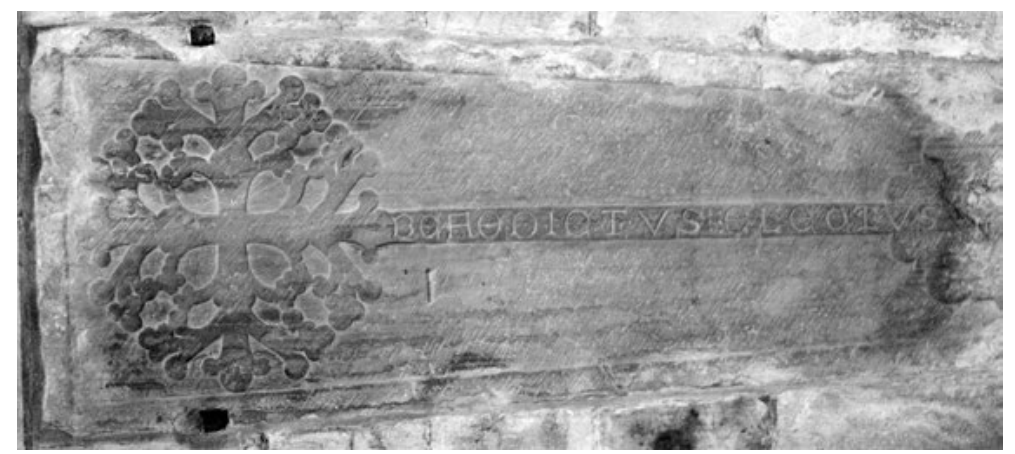

Figure 8: Funerary inscription on a so-called lily stone in Skara Cathedral (Skara 1), Skånings Hundred, at the tomb of Benedictus electus, 'Benedict elect', previously interpreted as the midtwelfth century bishop Bengt "the Good" of Skara. It should most probably be dated to the thirteenth century, and the identity of Benedictus is not certain. Photograph by Harald Faith-Ell.

16 The Burseryd bell bears the following runic inscription: Anno incarnationis Domini millesimo ducentesimo tricesimo octavo erat facta haec campana. Bero scripsit.

17 Stone inscriptions are found in Österplana, Kinne Hundred (Österplana 1); Husaby, Kinnefjärding Hundred (Husaby 1 and Husaby 3); Humla, Redväg Hundred (Humla 1); Tidavad, Vadsbo Hundred (Tidavad 1); Fors, Flundre Hundred (Fors 1); Skara, Skånings Hundred (Skara 1). Inscriptions on church bells are found in Bälinge, Kulling Hundred; Fors, Flundre Hundred; Humla, Redväg Hundred; Hjälstad, Vadsbo Hundred; Norra Härene, Kinnefjärding Hundred; Norra Åsarp, Redväg Hundred; Södra Ving, Ås Hundred; see Åmark (1960: s.v.). 
only on funerary monuments, baptismal fonts, and church bells - no Latin inscriptions on architectural elements or on other objects occur from the period.

Besides the geographical developments of the aforementioned epigraphic areas, a major new phenomenon concerning both runic and Latin epigraphic practice towards the end of the twelfth and the first part of the thirteenth century is the production of biscriptal and bilingual inscriptions, where both runes and Latin letters, as well as both Old Swedish and Latin, are used on the same artefact. The localities around Falköping, again, seem to have played an important role in this development. It is here, in fact, that almost all biscriptal/bilingual inscriptions in the province are concentrated. They constitute a unique corpus, which for the most part consists of funerary monuments either signed by or attributed to the stonemason magister Harald. ${ }^{18}$

Harald's opus consists of nine monuments. ${ }^{19}$ These inscriptions normally refer both to the buried individual and to the commissioner of the monument (a continuation of the Viking-Age runic tradition), in some cases together with Harald's signature, either in Latin: Haraldus or Haraldus magister (see Figure 9), or in Old Swedish: Haraldær or Haraldær stenmæstari. Sometimes a short prayer (Ave Maria) is also added. Since both the mason signatures and the rest of the inscriptions show the same duality regarding alphabet and language, it seems probable that not only Harald, or not only the client, were to some extent bilingual, but also that this signifies a general use of both languages and both scripts in certain strata of society in the Falköping area at the time.

A typical Harald inscription, which contains Old Swedish written in runes as well as both Old Swedish and Latin written in Latin letters, is a funerary monument from Ugglum, a few kilometres north of Falköping (see Figure 9). The text reads as follows (transliterated runes are in bold and Latin letters without bolding; an arch connecting two runes indicates a ligature):

18 The precise dating of Harald's inscriptions has been much debated, with suggestions, ranging from the second half of the twelfth century to the beginning of the thirteenth century, that have mainly been based on art-historical criteria. Through an in-depth study of palaeographical and linguistic aspects of these inscriptions, forthcoming studies by the authors of this paper will hopefully refine and develop this discussion further. Only one other inscription on stone combines runes and Latin letters, namely Vg 54/Husaby 2 on a funerary monument at Husaby Church, traditionally called "The tomb of Olof Skötkonung". Since this inscription is neither interpreted nor dated securely, it is difficult to analyse its relation to the Harald inscriptions. Furthermore, the material includes an inscription (Vg 221) on a thirteenth-century bell from Flakeberg Church that bears a prayer in Latin letters and a personal name in runes.

19 Gudhem (Vg 88/Gudhem 1, possibly by Harald), Kyrketorp (Vg 97/Kyrketorp 1, possibly by Harald, now lost), Sjögerås (Vg 131/Sjögerås 1, possibly by Harald, now lost), Slöta (Vg 146/Slöta 1, now lost), Södra Ving (Vg 165/Södra Ving 1), Ugglum (Vg 95/Ugglum 1), Valstad (Valstad 1), Valtorp (two inscriptions, of which one is Vg 96/Valtorp 1 and the other is the lost Valtorp 2). See Blennow (2016: 235-237) and Källström (2018). 


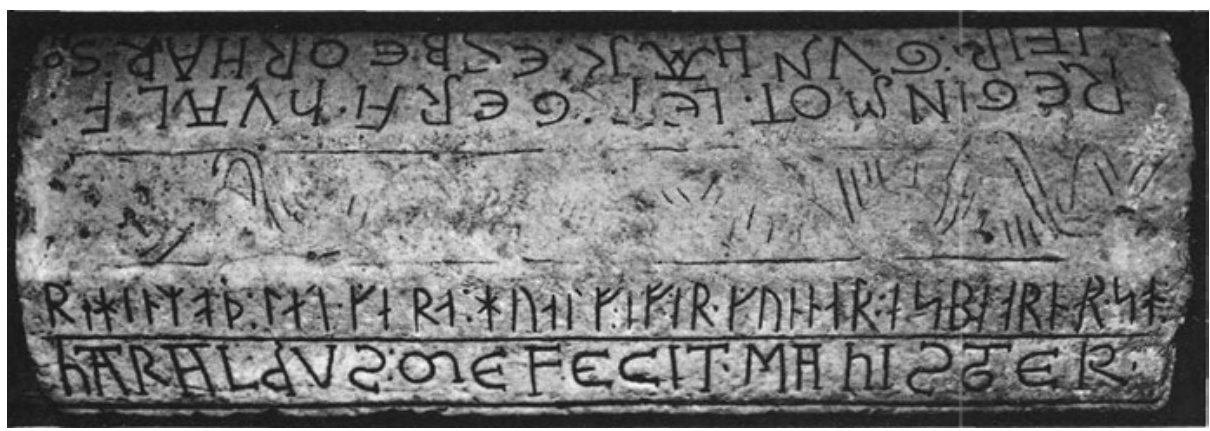

Figure 9: Funerary inscription from Ugglum Church (Vg 95/Ugglum 1), Gudhem Hundred (now in Historiska museet, Stockholm, inv. no. 3276:2). Photograph by Harald Faith-Ell.

Reginmot $\cdot$ let $\cdot$ gera $\cdot$ hvalf :

ifir : Gunnar : Esbeornar : son

rehinmop : læt · gæra : hualf : ifir · gunnar : æsbeornar $\cdot$ sôn :

Haraldus : me fecit : mahister •

Reginmod had this vault made for Gunnar, Åsbjörn's son. Master Harald made me.

The inscription starts with a passage in Latin letters and Old Swedish that conveys a memorial formula well known from many other runic inscriptions from both the Viking Age and the Middle Ages (see e.g. Palm 1992: 134-135, 137-138). The same content is then expressed in runes and Old Swedish. Lastly, we find the signature of the carver written in Latin letters and in the Latin language.

One Harald inscription, from Valtorp (Vg 96/Valtorp 1), falls out of the pattern in that it predominantly contains text in Latin and in the Latin alphabet, namely a lengthy poem in hexameters about the deceased person, probably named Florens, whereas only traces of a short runic inscription of uncertain reading are preserved. Though often misspelled and rather cryptic, the Latin text nevertheless attests the existence of advanced Latin knowledge in the early medieval Falköping area. ${ }^{20}$

20 The text reads: [Qui legis $i$ ]sta mea fata $n a(m)$ modo ride / [mors nil aet] atis $n(i) l$ parcit nobilitati. Florens / floreba $(m)$ bona fersbona cucn[t]afe [---] / [---]scu(m) nil caui defunctus ab orbe meau[i], tentatively interpreted as 'You who read this, look at my fate, but just laugh, because death pardons neither age nor nobility. I, Florens, flourished and was of a noble personality and owned goods, which I had not yet bequeathed to anyone. I migrated as deceased from earth' (Blennow 2016: 193-198). 


\section{The fourteenth century onwards: The stabilization of Latin epigraphy and decline of runic epigraphy}

Although not primarily included in our pilot study, the development of the epigraphic areas after the thirteenth century deserves some brief comments.

From the fourteenth century onwards, the epigraphic areas of Västergötland are subject to major changes. The runic tradition starts declining and, as a result, its geographical domains shrink. In contrast, the production and use of Latin epigraphy becomes stronger, and its hubs shift more clearly to religious and urban centres.

By the end of the thirteenth century, the runic tradition seems to have weakened significantly. No rune-inscribed funerary monuments are securely dated to the fourteenth century, and the only remnants of a possibly public use of the runes are two rune-inscribed bricks from Skara and Aranäs, which bear uninterpreted runic inscriptions, ${ }^{21}$ and a few biscriptal texts on church bells (see below). By this time, the runes thus seem to have lost their role in the public sphere in favour of inscriptions in the Latin alphabet. However, they still retain their place in more private texts, as several fourteenth-century rune-carved movable objects found in the town of Lödöse show.

As Annika Ström (2002: 18-23) has shown, Latin funerary inscriptions are distributed in three main areas in this period: the town of Skara, Varnhem Monastery, and the town of Lödöse. ${ }^{22}$ In these locations, almost no Latin inscriptions are preserved or known from before the fourteenth century, with the exception of one inscription in Skara Cathedral (Skara 1, see Figure 8), even though the rural area around Skara developed as an epigraphic area in the thirteenth century. We can thus detect another great shift in the geographical distribution of Latin epigraphy, whereby both early towns and monasteries now obviously offered the strongest incentives for the making of epigraphic monuments. Latin epigraphy is now found exclusively on funerary monuments and church bells, and not, as in the preceding centuries, on baptismal fonts or architectural elements.

Latin inscriptions on church bells are sparse in the twelfth and thirteenth centuries, and in fact, the main production of church-bell inscriptions stems from the fourteenth century onwards, with a peak in the first half of the sixteenth century. They are spread more or less evenly all over the province, which suggests that decidedly different needs were at play regarding inscribed church bells. They are almost exclusively in Latin letters, except for a group of four church bells from the fourteenth century where the biscriptal tradition that emerged in the previous century finds a continuation. ${ }^{23}$ All of them are signed by the same craftsman, Haquinus. Similarly to

21 Vg Fv1973;201A, Skara, and Vg NOR2001;28, Aranäs.

22 According to Ström's study, a total of sixteen inscriptions from the fourteenth and fifteenth centuries are preserved from Skara, ten from Varnhem Monastery, and eight from the town of Lödöse.

23 Vg 222, Malma Church (Viste Hundred); Vg 245, Herrljunga Church (Kulling Hundred); Vg 247, Hössna Church (Redväg Hundred); Vg 253, Älvsered Church (Kind Hundred). 
the stonemason Harald, Haquinus uses both runes, for the text Ave Maria Jesus, and Latin letters, for his own signature in the Latin language. Differently from Harald's oeuvre, which was mostly concentrated in a geographically delineated area around Falköping, Haquinus' inscriptions are spread over a large area in Västergötland, which is further proof of the fact that craftsmen producing church bells, like those producing baptismal fonts, served wider areas of the province, as will be touched upon briefly below.

\section{Production, distribution, and epigraphic areas}

A question of importance when it comes to defining epigraphic areas is the fact that the final location of the epigraphic monument may or may not coincide with the place of its production. This becomes especially evident in the case of material such as baptismal fonts and church bells, objects where the impetus of production, from the twelfth century and after, must have been less related to cultural and social centres. Each parish would need a font and one or more church bells, and it is probable that these objects were to some extent prefabricated at a workshop near a stone quarry and/or a stonemason's workshop, and then distributed all over the province. We know that even ponderous objects such as these could be moved over long distances, in addition to the fact that craftsmen were obviously also movable.

For example, the baptismal font in Åkirkeby on the Danish island of Bornholm (DR 373) was made by a stonemason of Gotlandic origin, Sigraiv, as shown by his signature on the font (DR, cols 427-431). ${ }^{24}$ Another example is the oeuvre of Master Harald which, as discussed above, is located very neatly in a circle around today's Falköping, with the exception of one funerary monument found around fifty kilometres south the town, in the church of Södra Ving. A third example may be the stonemason Alexander, who left his signature in Latin on the baptismal font in Fors in the north-western part of Västergötland (Fors 1), and was also the craftsman behind two fonts with Latin inscriptions in medieval Denmark: in Tikøb, Sjælland, and in Fjelie, Skåne (Blennow 2016: 45-48, 116-120). The literary skills and status of a stonemason may, regardless of other factors, also have been the incentive for the making of an inscription, especially in the case of baptismal fonts, where inscriptions often consist solely of the craftsman's signature.

A case in point is the striking geographical pattern shown by the distribution of inscribed baptismal fonts in Västergötland, which displays a clear division between runic inscriptions and Latin inscriptions (see Figure 10): the fonts with Latin inscriptions are found in the central and northern parts of the province, while fonts

24 The inscription ends with a somewhat damaged part, which can be reconstructed as Sigraif $R$ mestari 'Master Sigraiv'. 
with runic inscriptions are located in the southern parts. Such patterns raise the question of where the decisive factors for the making of an epigraphic monument, and in determining which language and script were used, are to be found, whether in the area of use of an object, or rather in the area of its production.

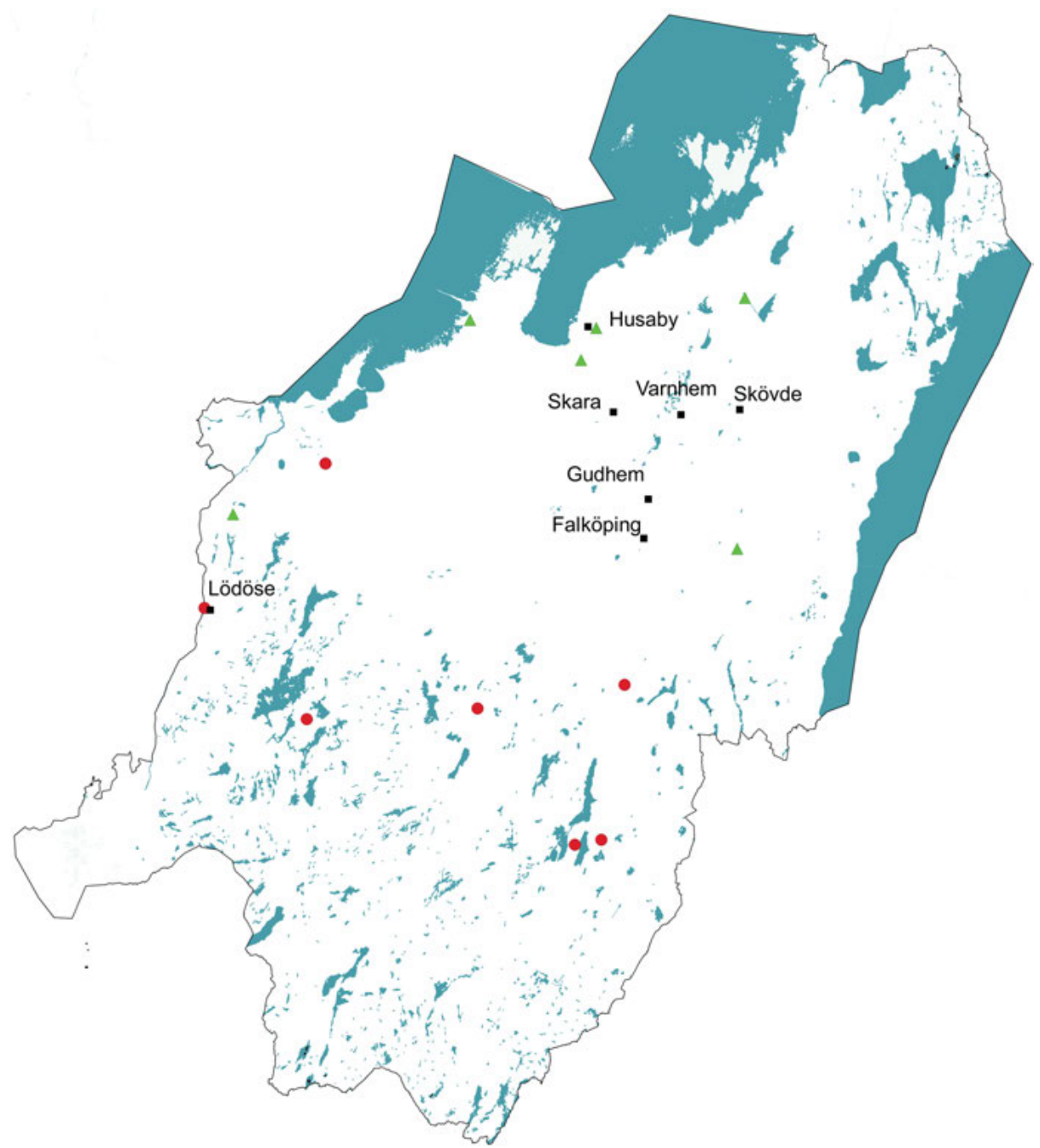

Figure 10: Map of the occurrence of medieval baptismal fonts in Västergötland with runic (red dots) and Latin (green triangles) inscriptions. Map by Alessandro Palumbo. 


\section{Conclusions}

In this pilot study, we have investigated the establishment and development of runic and Latin epigraphy in the twelfth and thirteenth centuries in the Swedish province of Västergötland. We have compared the geographical spread of these two traditions in order to identify hubs of epigraphic culture, here called epigraphic areas, and to track their evolution and mutual relationship during the twelfth and thirteenth centuries. By means of this comparison, we have been able to detect several complex and dynamic shifts in the use and distribution of runic and Latin epigraphic literacy.

Before the period in focus here, the only form of epigraphy present in Västergötland was the runic one. During the late Viking Age, rune stones were mainly distributed in three separate areas: Vadsbo in the north-east, Redväg in the central part, and Kålland in the mid-northern part of the province. The partly contemporary early Christian grave monuments, both those inscribed with runes and the uninscribed ones, further accentuate the importance of the mid-northern area of the province, as they are primarily found in Kålland Hundred and in the nearby area of Kinnekulle.

This picture changes drastically in the twelfth century, as two major events affect the epigraphic areas of Västergötland: Latin epigraphy is introduced, and the runic tradition shifts its geographical domain.

One of the two main areas where Latin epigraphy established itself in Västergötland in the twelfth century is Kinnekulle in the mid-northern part of the province. As mentioned above, several sites in Kinnekulle and in the neighbouring area of Kålland constituted the main centres of production of the so-called early Christian grave monuments in the eleventh century. This development of an intensified use of monumental epigraphy in the mid-eleventh century possibly created the preconditions for Latin epigraphy to be introduced to the Kinnekulle area in the early twelfth century. Several of the Latin inscriptions here are dated to the early twelfth century, which may point to continued epigraphic activity in the area.

The beginning of the twelfth century further marks the start of a coexistence of runic and Latin epigraphy that in this part of Sweden will last for over two centuries. This coexistence is evident on several levels, not least the geographical one, as both traditions flourish in a new epigraphic area located around today's Falköping. This town is not historically attested until 1281, but the epigraphic evidence gathered in this study testifies to intense sociocultural activity in the area already in the twelfth century.

As regards the runic tradition, the older Viking-Age epigraphic areas in Redväg, Kålland, and Vadsbo decline in importance in favour of this new hub of written culture, which also implies that the focal area for runic epigraphic production now appears more centralized compared with the three separately located VikingAge epigraphic areas.

The Falköping area shows not only a comparatively high number of Latin and runic inscriptions but also signs of a high level of writing competence. Where the 
Latin corpus is concerned, this is shown by inscriptions whose composition represents a clear break with the runic funerary epigraphy. The use of stylized Latin, poetry, and elaborate formulas furthermore indicates the presence of individuals who were very well versed in the Latin language. Where runic written culture is concerned, its vitality in this area is indicated, among other things, by a number of innovative traits in the writing system used, which seem to have originated here and spread later to other Swedish provinces. Moreover, some runic inscriptions in this area also show clear influences from the Latin epigraphic tradition, which can be seen in the orthographical conventions employed, in the presence of elements in the Latin language, and in the use of formulas inspired by continental Latin epigraphy.

In the hundreds around Falköping, therefore, we find during the twelfth century a simultaneous occurrence of a strong Latin and a strong runic epigraphic tradition. Here, we witness a unique intersection of the two written cultures, which seem to have reinforced each other, as both appear to be flourishing and expanding at the turn of the thirteenth century.

The two main epigraphic areas of Västergötland in the twelfth century, Kinnekulle and Falköping, differ in several aspects from each other. Kinnekulle is almost exclusively a Latin epigraphic area - no rune inscriptions are attested here, apart from the funerary monument in Husaby (Vg 54/Husaby 2). Moreover, the monuments here are characterized by a higher grade of "professionalization" with regard to both craftsmanship and religious organization, with craftsmen's signatures, liturgical inscriptions, and mostly institutional inscriptions, rather than texts connected to single individuals. Husaby, as a remarkably big church founded at an early date, is a signifier of religious importance that could have attracted this kind of epigraphic production. Yet another important factor might have been the stone quarries that we know were established at Kinnekulle in the twelfth century, where internationally recruited craftsmen would have been active, bringing with them Latin epigraphic culture from the continent.

From a sociocultural point of view, the epigraphic area of Falköping is remarkable because of its substantial production of inscriptions connected to wealthy individuals in the form of many funerary monuments. Furthermore, the epigraphic attestations from this area make clear that in Västergötland, not only clergymen and monks but also rich, influential, and educated lays of both genders participated in medieval literary culture and learned tradition, which shows that international cultural connections must have existed even outside the clerical milieu.

The evidence collected from the Falköping area seems to point towards both worldly and religious power becoming increasingly established around the location where the medieval town of Falköping was later to be founded. Thus, both the runic and Latin epigraphic areas show that "proto-Falköping" had by this time developed into one of the most important cultural, social, and religious centres of Västergötland, a fact that enriches our understanding of the early medieval history of the area, scantily documented in archaeological and other historical sources. 
Towards the end of the twelfth century and during the thirteenth century, it is possible to detect a general spread of both runic and Latin epigraphy over larger areas of Västergötland, which illustrates the renaissance that the two script cultures enjoyed in the province at the time. The two traditions seem to have bolstered each other, as they both continued to flourish in the area of Falköping and, moreover, established themselves in other areas, for instance in Vadsbo Hundred and around the town of Skara. Furthermore, the intersection of these two traditions resulted around the turn of the century in the production of not only bilingual but also biscriptal inscriptions, as seen in the oeuvre of Master Harald. While this phenomenon is too limited, both in the number of such inscriptions and in their geographical spread, to allow us to speak of a fully fledged blended, two-script culture, it is clear that the two traditions were closely intertwined in the area of Falköping, and that individuals gave expression to a truly mixed written culture in the epigraphic monuments that they created. This feature makes this particular epigraphic area unique for medieval Västergötland.

It is not until the fourteenth century - a period which lies outside the scope of this pilot study - that Latin epigraphy eventually gains the upper hand over the runic tradition, and reaches a stabilization in form, language, and function, in contrast to the rich variation typical of the preceding centuries. During this time, Latin epigraphy also shifts its geographical domains and is concentrated in the towns of Skara and Lödöse, as well as in the monastery at Varnhem. This change in the distribution of monumental Latin inscriptions shows the increasingly important role that monasteries and the growing towns played for the production of epigraphy. During the same period, formal and monumental runic epigraphy was rapidly declining, and is found only on a few church bells, whereas runes still seem to have been used on movable objects, as findings from the town of Lödöse witness.

As has been demonstrated in this paper, epigraphic studies can complement and add nuance to archaeological and historical sources to a high degree, and also, as in the case of Falköping, present entirely new evidence for the sociocultural importance of a region despite a lack of other sources from the twelfth and early thirteenth centuries. Moreover, this study shows that the combined investigation of runic and Latin epigraphy can shed new light on the development of a literate society in medieval Sweden.

\section{Bibliography}

Åmark, Mats. 1960. Sveriges medeltida kyrkklockor: bevarade och kända klockor. Stockholm: Almqvist \& Wiksell.

Blennow, Anna. 2016. Sveriges medeltida latinska inskrifter 1050-1250. Edition med språklig och paleografisk kommentar. Stockholm: Historiska museets förlag. 
Bonnier, Ann Catherine. 2012. "Alvastra kloster och kyrkobyggandet i Östergötland.” In: Munkar och magnater vid Vättern. Studier från forskningsprojektet "Det medeltida Alvastra", ed. Lars Ersgård, 7-88. Lund: Institutionen för arkeologi och antikens historia.

Carelli, Peter. 2001. En kapitalistisk anda: kulturella förändringar i 1100-talets Danmark. Stockholm: Almqvist \& Wiksell International.

Carlsson, Kristina \& Rune Ekre. 1980. Gamla Lödöse. Medeltidsstaden 21. Stockholm: Riksantikvarieämbetet.

Dahlberg, Markus. 1998. Skaratraktens kyrkor under äldre medeltid. Skara: Skaraborgs länsmuseum.

DS = Diplomatarium Suecanum (Svenskt Diplomatarium), published by Kungl. Vitterhets historie och antikvitetsakademien and Riksarkivet, 1829-.

Düwel, Klaus. 1989. "Der runenbeschriftete Holzgriff aus Schleswig - zur Deutung einer rätselhaften Inschrift." In: Ausgrabungen in Schleswig. Berichte und Studien. Vol. 7, Das archäologische Fundmaterial, vol. 1, ed. Volker Vogel, 43-82. Neumünster: Wachholtz.

Düwel, Klaus. 2001. "Mittelalterliche Amulette aus Holz und Blei mit lateinischen und runischen Inschriften." In: Ausgrabungen in Schleswig. Berichte und Studien. Vol. 15, Das archäologische Fundmaterial, vol. 2, ed. Volker Vogel, 227-302. Neumünster: Wachholtz.

Ertl, Karin. 1994. "Runen und Latein: Untersuchungen zu den skandinavischen Runeninschriften des Mittelalters in lateinischer Sprache." In: Runische Schriftkultur in kontinentalskandinavischer und -angelsächsischer Wechselbeziehung: internationales Symposium in der Werner-Reimers-Stiftung vom 24.-27. Juni 1992 in Bad Homburg, ed. Klaus Düwel, 328-390. Berlin: de Gruyter.

Franzén, Kristina. 2002. “Kyrkan i landskapet.” In: Västergötland. Landskapets kyrkor (Forskningsprojektet Sockenkyrkorna), ed. Markus Dahlberg, 13-32. Stockholm: Riksantikvarieämbetet.

Fv = Fornvännen. Tidskrift för svensk antikvarisk forskning, published by Kungl. Vitterhets Historie och Antikvitets Akademien. 1906-. Stockholm.

Gardell, Sölve. 1945. Gravmonument från Sveriges medeltid I-II, Stockholm: Wahlström \& Widstrand.

Gustavson, Helmer. 1994a. "Latin and Runes in Scandinavian Runic Inscriptions." In: Runische Schriftkultur in kontinental-skandinavischer und -angelsächsischer Wechselbeziehung: internationales Symposium in der Werner-Reimers-Stiftung vom 24.-27. Juni 1992 in Bad Homburg, ed. Klaus Düwel, 313-327. Berlin: de Gruyter.

Gustavson, Helmer. 1994b. "Runsk latinitet." In: Medeltida skrift- och språkkultur. Nordisk medeltidsliteracy $i$ ett diglossiskt och digrafiskt perspektiv II: nio föreläsningar från ett symposium i Stockholm våren 1992, ed. Inger Lindell, 61-77. Stockholm: Runica et mediævalia.

Gustavson, Helmer. 2013. “Lära sig och lära ut runor - med hjälp av futharken?” Situne Dei : 31-40. Holst Blennow, Anna. 2011. The Latin Consecrative Inscriptions in Prose of Churces and Altars in Rome 1046-1263. Miscellanea della Società Romana di Storia Patria LVI. Roma: Società di storia patria.

Karlsson, Jan O. M. 1993. "Klostren i det medeltida Sverige - en översiktlig sammanställning.” Hikuin 20: Kirkearkæologi i Norden 4: 113-122.

Klackenberg, Henrik. 1980. Skövde. Medeltidsstaden 28, Stockholm: Riksantikvarieämbetet. Klackenberg, Henrik. 1981. Falköping. Medeltidsstaden 27. Stockholm: Riksantikvarieämbetet. Kleivane, Elise. 2019. “To menn og Ave Maria i Hamarkaupangen.” Maal og minne 2: 69-99. Knirk, James E. 1994. "Learning to write with runes in medieval Norway." In: Medeltida skrift- och språkkultur. Nordisk medeltidsliteracy i ett diglossiskt och digrafiskt perspektiv II: nio 
föreläsningar från ett symposium i Stockholm våren 1992, ed. Inger Lindell, 169-212. Stockholm: Runica et mediævalia.

Knirk, James E. 1998. "Runic inscriptions containing Latin in Norway." In: Runeninschriften als Quellen interdisziplinärer Forschung: Abhandlungen des Vierten internationalen Symposiums über Runen und Runen-inschriften in Göttingen vom 4.-9. August 1995, ed. Klaus Düwel, 476-507. Berlin: de Gruyter.

Knirk, James E. 2010. "Dotted runes: where did they come from?" In: The Viking Age: Ireland and the West. Papers from the Proceedings of the Fifteenth Viking Congress, 18-27 August 2005, ed. John Sheehan \& Donnchadh Ó Corráin, 188-198. Dublin: Four Courts Press.

Källström, Magnus. 2013. "Vikingatida och medeltida skrifttraditioner. Några iakttagelser med utgångspunkt i det svenska runmaterialet." Futhark: International journal of runic studies 4: 101-128.

Källström, Magnus. 2015. "Gravhällsfragmentet från Tornby i Fornåsa i Östergötland och utvecklingen av några medeltida runformer." Futhark: International journal of runic studies 6: 107-142.

Källström, Magnus. 2018. "Haraldær stenmæstari - Haraldus magister: a case study on the interaction between runes and Roman script." In: Epigraphy in an intermedial context, ed. Alessia Bauer, Elise Kleivane \& Terje Spurkland, 59-74. Dublin: Four Courts Press.

Lindkvist, Thomas. 2012. "Land och rike. Västergötland och det svenska riket under medeltiden." In: Svärdet, ordet och pennan: kring människa, makt och rum i nordisk historia: festskrift till Nils Erik Villstrand den 24 maj 2012, ed. Christer Kuvaja \& Ann Catrin Östman, 515-532. Åbo: Historiska samfundet i Åbo.

Ljung, Cecilia. 2016. Under runristad häll: tidigkristna gravmonument i 1000-talets Sverige, 1-2. Stockholm Studies in Archaeology 67. Stockholm: Explicare.

Ljung, Cecilia. 2019. "Early Christian Grave Monuments and Ecclesiastical Developments in $11^{\text {th }}$-Century Sweden." Medieval Archaeology 63:1: 154-190.

NlyR $=$ Norges innskrifter med de yngre runer, ed. Magnus Olsen et al. 6 vols. to date (Oslo 1941-). NOR $=$ Nytt om runer. Meldingsblad om runeforskning 1-, 1986-.

Palm, Rune. 1992. Runor och regionalitet: studier av variation i de nordiska minnesinskrifterna. Uppsala: Institutionen för nordiska språk.

Palm, Rune. 1997. "Runkunskap under medeltid: en analysmodell och några resultat." In: Till Barbro: texter och tolkningar tillägnade Barbro Söderberg den 23 september 1997, ed. Roger Andersson \& Patrik Åström, 87-105. Stockholm: Institutionen för nordiska språk.

Palumbo, Alessandro. 2020. Skriftsystem i förändring: en grafematisk studie av de svenska medeltida runinskrifterna [Changing writing systems: a graphemic study of the Swedish medieval runic inscriptions]. Uppsala: Institutionen för nordiska språk.

Palumbo, Alessandro. Forthcoming. "How Latin is runic Latin? Thoughts on the influence of Latin writing on medieval runic orthography." In: Vergleichende Studien zur runischen Graphematik: Methodische Ansätze und digitale Umsetzung, ed. Edith Marold \& Christiane Zimmermann. Uppsala: Institutionen för nordiska språk.

Peterson, Lena. 1994. "Runorna som skriftsystem". In: Runmärkt: från brev till klotter. Runorna under medeltiden, ed. Solbritt Benneth et al., 63-74. Stockholm: Carlsson.

Seim, Karin Fjellhammer. 2010. "Evidence of Runic and Roman Script in Contact in Post-Viking Age Norway." Futhark: International journal of runic studies 1: 189-196.

Sigsjö, Ragnar, 1980: Skara. Medeltidsstaden 24. Stockholm: Riksantikarieämbetet.

Spurkland, Terje. 2001. "Scandinavian Medieval Runic Inscriptions - an Interface Between Literacy and Orality?" In: Roman, runes and ogham: medieval inscriptions in the insular world and on the continent, ed. John Higgitt, Katherine Forsyth \& David N. Parsons, 121-128. Donington: Shaun Tyas. 
Spurkland, Terje. 2004. “Literacy and 'Runacy' in Medieval Scandinavia." In: Scandinavia and Europe 800-1350: Contact, Conflict, and Coexistence, ed. Jonathan Adams \& Katherine Holman, 333-344. Turnhout: Brepols.

$\mathrm{SRI}=$ Sveriges runinskrifter, published by Kungl. Vitterhets Historie och Antikvitets Akademien. 1900-. Stockholm.

Steenholt Olesen, Rikke. 2007. Fra biarghrúnar til Ave sanctissima Maria: Studier i danske runeindskrifter fra middelalderen. Unpublished Ph.d. thesis. Copenhagen: University of Copenhagen. http://cms.ku.dk//upload/application/pdf/e3d23f57/RSO-phd-afhandling -20okt2008.pdf (1 October 2020).

Ström, Annika. 2002. Monumental Messages. Latin Inscriptions on Tombstones and Church Bells in Medieval Sweden. Stockholm: Runica et mediaevalia.

Söderberg, Barbro \& Inger Larsson. 1993. Nordisk medeltidsliteracy i ett diglossiskt och digrafiskt perspektiv. Stockholm: Institutionen för nordiska språk.

Theliander, Claes. 2004. Det medeltida Västergötland. En arkeologisk guidebok. Lund: Historiska media.

$\mathrm{Vg}+$ number $=$ Runic inscription in SRI 5.

Vretemark, Maria. 2014. "Fru Sigrids gård i Varnhem.” In: Medeltida storgårdar: 15 uppsatser om ett tvärvetenskapligt forskningsproblem, ed. Olof Karsvall \& Kristofer Jupiter, 131-143. Uppsala: Kungl. Gustav Adolfs Akademien för svensk folkkultur. 
